\section{Answers to Monod}

Beyond Chance and Necessity. Edited by John Lewis. Pp. xi+141. (Garnstone: London, 1974.) £2.95.

Wirfo Jacques Monod, in Chance and Necessity, classed Christians and Marxists, along with witch doctors, as "animists" who attribute a will to nature, a reply was to be expected. These essays, published as part of the Teilhard Study Library, are part of that reply: Beyond Chance and Necessity brings together a number of people who have little in common other than their disagreement with Monod.

Monod argued that our present cultural confusion arises because our ethical beliefs are based on various pictures of the world, in particular the Christian myth, which ascribes a purpose to the Universe and a special role for man in that purpose, whereas our economic existence depends on the scientific world picture, which does not admit explanations in terms of purposes or final causes, and which sees man as the accidental consequence of natural selection acting on random mutation. He urges us to recognise the distinction between 'objective' statements proper to science, and statements of value which cannot be derived from science. The 'principle of objectivity'-the avoidance of teleological explanation in science-he sees as itself a moral commitment, necessary for the practice of science and, therefore, not derivable from it.

Mary Warnock accuses Monod of arguing in a circle. If science is based on the assumption that there are no purposes in the Universe, one cannot then deduce from science that there is no purpose, and no special role for man. Monod's picture of the world is, in fact, quite consistent with God as a 'first cause', who created a world capable of generating life, and who even retains an interest in that world. This argument is taken further from a Christian standpoint by Arthur Peacocke. He argues, by analogy with statistical mechanics, that the randomness of mutation does not mean that there are no laws of evolution; a point made by other contributors, and one I would accept. For a Christian, however, God as a first cause who designed the laws of nature and the initial conditions to hold the potentiality of life and who then let the Universe run, is not enough. Peacocke is critical of the concept of a "God of the gaps", invoked to explain those phenomena which science cannot, because that can lead only to a dwindling role for God. Instead he sees God as imminent in all natural processes, working through the laws of nature and not by suspending them.
My difficulty here is not so much that I disagree with him as that I cannot see what he can possibly mean. If God is simply another name for the laws of nature, then not only is there no need for that hypothesis, there is no need for the term itself.

The defence of Marx is taken up by John Lewis. It is perfectly possible to be a good philosopher without knowing any biology; unhappily, Dr Lewis writes as if he understood biology when it is quite clear that he does not. That gives such an air of insincerity to his essay that I found it impossible to pay serious attention to it. That is a pity, because I think he is right in arguing that Marx and Engles were not animists in Monod's sense. They saw 'dialectical laws' not as a mind or purpose in nature, but as observable regularities in the behaviour of natural systems.

Joseph Needham also comes to the defence of Marxism. He quotes with approval the antimechanist views expressed by Soviet Marxist scientists in the early 1930s. That will not quite do. A few years later, Marxist philosophers, arguing that the gene was an undialectical entity because it controls development without being influenced by it, supported the destruction of biology in the Soviet Union; at the same time, men who believed that the cell is a machine (not, it is true, a clock-more a tape-recorder) were revolutionising biology

The most interesting essays in the book are written from within evolution theory and molecular biology, by $\mathrm{C}$. $\mathrm{H}$. Waddington and Robin Monro. Waddington was provoked into contributing by a report that Monod has accused him of Lysenkoism. I do not know whether the report is true, but I am glad of the result; if a man is accused of Lysenkoism it does concentrate the mind wonderfully. Waddington gives an unambiguous account of the significance of genetic assimilation. Monro criticises Monod's excessive reliance on molecular concepts in biology. He first argues that the 'central dogma'-that information cannot pass from protein to nucleic acids-is not necessary for the truth of Weismannism, An 'acquired character' is not usually reflected in a changed amino acid sequence in protein, so even if the central dogma were false, most acquired characters could not be transmitted. Monro goes on to argue that the dogma is not sufficient either, because some kind of germinal selection may produce Lamarckian effects (the same idea is worked out in more detail by Waddington).

The main difficulty in assessing this controversy is that at least two separate issues are being confused. The first is the relationship between science and ethics. There, I think Monod was right in saying that the scientific world picture has been built by abjuring fina' causes. I have little sympathy with those of his critics who dislike mech anistic theories in science because they lack moral uplift. But there is second issue, concerning the strategy of scientific research; there, I think Monod's critics have a case. I do not think it will prove possible to explain biology in molecular terms in quite the way Monod hopes. For example, he writes "personally I am convinced that in the end only the shape-recognising and stereospecific binding properties of proteins will provide the key to these phenomena" (that is of development). My own guess is that it will no more be possible to understand the shapes of embryos in terms of the properties of proteins than it is possible to understand the shapes of the waves generated in Jabotinski's reaction in terms of the shapes of the constituent molecules. Of course, theories of development will be dependent on and consistent with molecular biology but they will not be discovered by thinking only at the molecular level.

This guess may be wrong. But then, I wish I was as sure of anything as Monod is of everything. How a man can write "This central concept of modern biology is no longer one among other possible or even conceivable hvpothesis, the only one compatible with observed and tested fact. And nothing warrants the supposition (or the hope) that conceptions about this should, or ever could be revised", and claim to be a Popperian. I do not know.

John Maynard Smith

\section{Critical look at the LMFBR}

The Liquid Metal Fast Breeder Reactor. By Thomas B. Cochran. Pp. xiv +271. (Johns Hopkins University: Baltimore and London, 1974.) \$6.95.

I CANNOT do better than quote from the preface:

"In this monograph Thomas Cochran takcs a critical look at the economic and environmental arguments which have been made in favor of an early introduction of the liquid metal fast breeder reactor (LMFBR) as a central component of the United States electrical energy system."

Taking a number of published United States (US) reports, particularly the cost/benefit analyses put out by the US Atomic Energy Commission in 1970 and 1972, he considers in reasonable detail the choice of discount rate, the assessment of generating costs, the validity of currently assumed perform- 